\title{
Reproduction and nutritional values of the edible limpet Nacella magellanica (Gastropoda: Patellogastropoda)
}

\author{
Rocío A. Nieto Vilela ${ }^{1,2}$, Mariano Cumplido ${ }^{1}$, Yamila González Giorgis ${ }^{2}$, Mónica N. Gil ${ }^{3}$, \\ Gregorio Bigatti 1,2,4 \\ ${ }^{1}$ LARBIM-IBIOMAR (CONICET), Boulevard Brown 2915 (U9120ACD), Puerto Madryn, Chubut, Argentina. \\ (RANV) (Corresponding author) E-mail: nieto@ cenpat-conicet.gob.ar. ORCID iD: https://orcid.org/0000-0002-8681-0906 \\ (MC) E-mail: cumplido@ @enpat-conicet.gob.ar. ORCID iD: https://orcid.org/0000-0001-9776-8865 \\ (GB) E-mail: gbigatti@cenpat-conicet.gob.ar. ORCID iD: https://orcid.org/0000-0001-7053-6802 \\ ${ }^{2}$ Universidad Nacional de la Patagonia San Juan Bosco (UNPSJB), Boulevard Brown 2915, Puerto Madryn, Chubut, \\ Argentina. \\ (YGG) E-mail: yamila.gonzalez.g@ gmail.com. ORCID iD: https://orcid.org/0000-0002-6977-4114 \\ ${ }^{3}$ LAQUIAE-CESIMAR (CONICET), Boulevard Brown 2915 (U9120ACD), Puerto Madryn, Chubut, Argentina. \\ (MNG) E-mail: monicagil @ cenpat-conicet.gob.ar. ORCID iD: https://orcid.org/0000-0001-9802-0488 \\ ${ }^{4}$ Universidad Espíritu Santo, Km 2.5 vía Puntilla-Samborondón, Ecuador.
}

\begin{abstract}
Summary: Nacella magellanica is an edible limpet that has been consumed since pre-Hispanic times by human populations along the coasts of Patagonia, but studies of its nutritional value and reproduction are not yet available. We investigated the reproductive cycle and the seasonal variation in the nutritional composition (proteins, lipids and carbohydrates) of the whole body of this limpet in order to analyse some aspects of its importance as a formal fishery resource. Throughout a single year, the spawning period extended over all months except June in males, while females spawned from late winter to spring, with an increase from August to November. The nutritional data obtained for N. magellanica are within the ranges of widely consumed species of molluscs, with annual average values of $29.8 \%$ proteins, $2.7 \%$ lipids and $1.8 \%$ carbohydrates. The best nutritional values for human consumption (highest concentration of proteins, body weight), avoiding the reproductive period, were found in April but taking into account the minimum size of capture. Our results are useful for increasing the policies aimed at managing this abundant edible limpet as a formal resource, since it is widely consumed in southern South America.
\end{abstract}

Keywords: marine gastropods; fishery resources; biochemical composition; reproduction; limpets.

Reproducción y valores nutricionales de la lapa comestible Nacella magellanica (Gastropoda: Patellogastropoda)

Resumen: Nacella magellanica es un caracol comestible, consumido desde tiempos prehispánicos por poblaciones a lo largo de las costas patagónicas. Sin embargo, aún no existen estudios sobre sus valores nutricionales ni su ciclo reproductivo. En este trabajo se estudió el ciclo reproductivo y la variación estacional en su composición nutricional (proteínas, lípidos y carbohidratos) en todo el cuerpo de la lapa, para analizar algunos aspectos de su importancia como recurso pesquero formal. El período de liberación de gametas en los machos se extendió a lo largo de todo el año, mientras que en las hembras fue desde el invierno tardío hasta la primavera, con un incremento desde agosto a noviembre. La información nutricional obtenida para $N$. magellanica se encuentra dentro de los rangos de otras especies de moluscos ampliamente consumidos, con promedios anuales de proteínas de $29.8 \%, 2.7 \%$ de lípidos y $1.8 \%$ de carbohidratos. Los mejores valores nutricionales para el consumo humano (mayor concentración de proteínas y peso corporal), evitando el período reproductivo, se encontraron durante abril, aunque habría que tener en cuenta el tamaño mínimo de captura. Nuestros resultados son útiles para incrementar las políticas existentes para el manejo de esta abundante lapa comestible como un recurso formal, ya que es consumida ampliamente en el sur de Sudamérica.

Palabras clave: gasterópodos marinos; recursos pesqueros; composición bioquímica; reproducción; lapas.

Citation/Como citar este artículo: Nieto Vilela R.A., Cumplido M., González Giorgis Y., Gil M.N., Bigatti G. 2019. Reproduction and nutritional values of the edible limpet Nacella magellanica (Gastropoda: Patellogastropoda). Sci. Mar. 83(3): 237-245. https://doi.org/10.3989/scimar.04825.06A

Editor: M. Ramón.

Received: June 26, 2018. Accepted: April 11, 2019. Published: June 19, 2019.

Copyright: ( 2019 CSIC. This is an open-access article distributed under the terms of the Creative Commons Attribution 4.0 International (CC BY 4.0) License. 


\section{INTRODUCTION}

Marine molluscs are abundant and easy to collect, and possess healthful properties such as a high proportion of proteins and a low level of saturated fatty acids (Isay and Busarova 1984, Manzano and Aranda 1998, D'Armas et al. 2010), making them a desirable seafood. Several studies have highlighted the dietary value of marine resources, and particularly of sea snails, for human consumption (Leiva and Castilla 2002, Vasconcelos et al. 2008, Bigatti et al. 2015). Therefore, knowledge of the nutritional composition of potential marine food can increase the possibilities for alternative foods worldwide. Studies on marine invertebrates have demonstrated that the reproductive strategies provide valuable information for fisheries regarding marine population dynamics (Underwood 1979, Collin 2003, Bigatti et al. 2008).

Coastal gastropod species such as limpets are consumed worldwide (Branch 1975, Pombo and Escofet 1996, Castilla 1999). In southern South America, limpets of the genus Nacella are commercially exploited in Chile and captured manually in Argentina from the provinces of Tierra del Fuego (Conti et al. 2012) to Chubut. The species Nacella magellanica was a resource widely used by the native populations of the Patagonian and Fueguian coasts in pre-Hispanic times (Gómez Otero et al. 1998, Orquera 1999, De Aranzamendi et al. 2009). At present, the harvesting of gastropods in Atlantic Patagonia is restricted to artisanal fisheries (Elías and Pereiro 2003). Therefore, owing to its high abundance, the current consumption and the simplicity of collection during low tides, $N$. magellani$\mathrm{ca}$ could become a formal artisanal fishery resource on the Patagonian Atlantic coasts.

$N$. magellanica has a wide distribution around the Magellanic region in southern South America, from Puerto Montt in the Pacific Ocean $\left(42^{\circ} \mathrm{S}\right)$ to the Buenos Aires province in the Atlantic Ocean $\left(35^{\circ} \mathrm{S}\right)$, including the Strait of Magellan, Cape Horn, Tierra del Fuego and the Malvinas Islands (Powell 1973, Pastorino 1995, González-Wevar et al. 2012). The genus Nacella is a broadcast spawner (it releases its gametes into the water) (Morriconi 1999, González-Wevar et al. 2012) and, like many other marine gastropods, its reproduction is correlated with the photoperiod and the water temperature (Morriconi 1999, Bigatti et al. 2008, Cumplido et al. 2010).

In recent years, $N$. magellanica has been extended as an incipient resource to the internal markets in Argentina, without any form of official control. This study is accordingly aimed at adding to a series of efforts made to establish regulatory policies for marine gastropod fisheries in northern Patagonia (Bigatti and Ciocco 2008, Penchaszadeh et al. 2009, Bigatti et al. 2015, among others).

The study reported here investigated for the first time the reproductive cycle and seasonal variation in total body mass and biochemical composition of $N$. magellanica in order to determine its nutritional values. The results obtained for this coastal resource can be useful for strengthening the management policies of several marine gastropods in the zone.

\section{MATERIALS AND METHODS}

\section{Sampling}

From January to December 2012, 50 specimens of Nacella magellanica were collected each month on the rocky intertidal shore of Punta Ninfas, Chubut (42 $58^{\prime} 42^{\prime \prime}$ S, $\left.64^{\circ} 18^{\prime} 33^{\prime \prime} \mathrm{W}\right)$. The analysis were made only with limpets above the maturity size $[1.73 \mathrm{~cm}$ high in females and $1.5 \mathrm{~cm}$ in males, sensu Nieto Vilela (2014)]. Unfortunately, no individuals could be collected during the month of May because the extreme weather conditions made it impossible to access to the sampling site. Punta Ninfas is located in the open sea, about $100 \mathrm{~km}$ from the city of Puerto Madryn, an area lacking fishing activity and inhabited by a stable community of marine elephants (Mirounga leonina) and particularly frequented by outdoor tourists.

All the specimens collected were taken directly to the laboratory and 30 were fixed in Bouin's fluid for $48 \mathrm{~h}$ and stored in 70\% (v/v) aqueous ethanol for histology. Because physical procedures enhance spawning in other molluscs (Velasco et al. 2007, Aji 2011), no sand depuration was performed and the biofilm over the shell was not removed. For each sampling, morphometric measurements were recorded on 30 individuals with callipers (precision $0.1 \mathrm{~mm}$ ) to establish the height, length and width. To determine the total weight, each shell was removed and the shell and body weights were recorded on a digital balance (precision $\pm 0.001 \mathrm{~g}$ ). Sex was determined on the basis of gonadal frotis under an optical microscope and related to gonadal colour: females were green and males yellow (see Results). From the total of sampled individuals, 5 specimens were used for nutritional values and 5 were used for ash determination. The 10 remaining specimens were used as a back-up, because in the process of shell extraction the tissue was often broken, making the specimens useless for nutritional composition determination or histological gonadal analysis.

\section{Gonadal cycle}

Each month, only around 10 individuals were suitable for gonadal determination (Table 1). Gonads were processed following standard histological procedures to study the annual cycle, as described by several

Table 1. - Number of individuals per gametogenic cycle of the 30 analysed per month.

\begin{tabular}{lccc}
\hline & Analyzable & Parasited & Sand/Indet \\
\hline January & 10 & 4 & 16 \\
February & 10 & 3 & 17 \\
March & 10 & 1 & 19 \\
April & 10 & 2 & 18 \\
June & 12 & 0 & 18 \\
July & 12 & 0 & 18 \\
August & 11 & 1 & 18 \\
September & 10 & 0 & 20 \\
October & 11 & 2 & 17 \\
November & 10 & 2 & 18 \\
December & 12 & 2 & 16 \\
\hline
\end{tabular}


Table 2. - Stages of gametogenic cycle in males and females.

\begin{tabular}{|c|c|c|}
\hline Stages & Female & Male \\
\hline 1. Developing & $\begin{array}{l}\text { Gonads formed by tubules supported by a germinal } \\
\text { epithelium lying alongside (Fig. 1). The oocytes prolifer- } \\
\text { ate inside the tubule attached to the wall. The basophilic } \\
\text { oocytes }(40-80 \mu \mathrm{m} \text { ) were usually of pyriform shape. The } \\
\text { oocytes also had a conspicuous external membrane and } \\
\text { were found next to companion cells. }\end{array}$ & $\begin{array}{l}\text { The tubules were associated with multiple layers of sper- } \\
\text { matogonia (Fig. 1). In this stage, the lumen of the tubules } \\
\text { contained some empty space along with some spermato- } \\
\text { cytes and spermatids. }\end{array}$ \\
\hline 2. Ripe & $\begin{array}{l}\text { Increase in oocyte diameter. Short distance between the } \\
\text { mature acidophilic oocytes, producing rigtht edges in the } \\
\text { mature oocytes }(100-140 \mu \mathrm{m} \text {, Figs } 1 \text { and } 2) \text {. }\end{array}$ & $\begin{array}{l}\text { A minimum of empty space was observed in the tubules, } \\
\text { while spermatocytes (SC) and spermatozoa (S) were } \\
\text { present (Fig. 1). }\end{array}$ \\
\hline 3. Spawned & $\begin{array}{l}\text { Empty tubule lumen. Mature oocytes attached to the } \\
\text { lumen were very uncommon, while the basophilic oocytes } \\
\text { were more abundant (Figs } 1 \text { and } 3 \text { ). The lumen contained } \\
\text { some athresic oocytes, and the trabeculae became more } \\
\text { enlarged. }\end{array}$ & $\begin{array}{l}\text { At this stage, the spermatogonia were formed by two or } \\
\text { three layers, whereas the spermatozoa became concentrat- } \\
\text { ed in the centre of the tubule (Fig. 1). Epididymis full of } \\
\text { mature spermatocytes. }\end{array}$ \\
\hline 4. Resorption & $\begin{array}{l}\text { The oocytes exhibited an irregular shape and size, and the } \\
\text { follicular walls became more conspicuous (Figs } 1 \text { and } 4 \text { ). } \\
\text { Presence of phagocytic-nutritive cells. }\end{array}$ & $\begin{array}{l}\text { The spermatozoa began to withdraw from the tubules and } \\
\text { became separated from each other while phagocytes were } \\
\text { present in the centre of the tubules (Fig. 1). }\end{array}$ \\
\hline
\end{tabular}

authors (Ramón and Amor 2002, Horn et al. 2005, Mazurkiewicz and Pokryszko 2005). The gonad was sectioned in anteroposterior slices (toward both front and back), embedded in paraffin and sectioned at 5 to 7 $\mu \mathrm{m}$ with a digital microtome (Leica), then heated for 24 $\mathrm{h}$ at $60^{\circ} \mathrm{C}$, and finally stained with haematoxylin and eosin (Gabe 1968).

Each sample was observed by light microscopy (Zeiss Axiostar, Germany) and photographed with a digital camera (Sound Vision 2.0). For each female, the gonadal cycle was estimated by oocyte diameter measurements (length and width mean) in all cells with a visible nucleolus using the ZEN 2.3.0.13 program. Between 10 and 100 oocytes with a visible nucleolus were measured in every female. The gametogenic cycle of both sexes was divided into four stages (Table 2) according to the stage of the reproductive cells; the classification was based on previous studies on Patagonian gastropods (Morriconi 1999, Bigatti et al. 2008, Averbuj et al. 2010) (Fig. 1).

\section{Nutritional composition}

For nutritional value determination, five randomly selected individuals with a size range of 0.9 to 2.7 $\mathrm{cm}$ height were analysed monthly. The determination was performed in males and females together, because both sexes are collected for consumption at the same time due to the absence of external sexual dimorphism. Total body masses were placed on aluminium film and heated at $60^{\circ} \mathrm{C}$ to constant weight. Dried tissues were triturated before sample processing to obtain a composite sample and an average monthly value for protein, lipid and carbohydrate content.

These determinations were performed by colorimetry according to the respective protocols of Lowry et al. (1951) using albumin as standard, Zöllner and Kirsch (1962) using cholesterol as standard and Fraga (1956) using glucose as standard. The measurements were made in a Hewlett Packard Model 8452A spectrophotometer, and the results were expressed as percent dry weight of tissues.
For ash determination, a single aliquot of wet body mass of five individuals was first heated at $60^{\circ} \mathrm{C}$ until the dried weight (DW) became constant. Thereafter, the sample was calcinated in a muffle oven at $550^{\circ} \mathrm{C}$ for $12 \mathrm{~h}$ and the weight of the resulting ash $(\mathrm{CW})$ was recorded. The percent ash content was calculated as $(\mathrm{CW} / \mathrm{DW}) \times 100$. The estimation of moisture content was performed with the same aliquot of the monthly wet sample by recording the initial weight (IW) and the value obtained after heating at $80^{\circ} \mathrm{C}$ to constant weight $(\mathrm{CW})$. The percent moisture content was then expressed as $((\mathrm{IW}-\mathrm{CW}) / \mathrm{IW}) \times 100$.

\section{Statistical analyses}

Because the parametric assumption was not met, differences between weight and length in males and females were evaluated with Wilcoxon and MannWhitney tests. Differences between average oocyte size and seasonal biochemical comparisons were assessed with a Kruskal-Wallis test. For significant results $(\mathrm{P}<0.05)$ a pairwise comparison test of subgroups was applied. The sex ratio was determined and compared with a $1: 1$ proportion by a chi-squared test. All the testes and modal determination were performed with the Statistica 7.0 software package (StatSoft, Inc., Tulsa).

To infer whether the sea surface temperature (SST) in ${ }^{\circ} \mathrm{C}$ and the gametogenic cycle were associated, we made in situ measurements in each sampling event and estimated the data from standard mapped satellite images (SMIs, NOAA, http:// oceancolor.gsfc.nasa.gov/) using those of seasonal satellite-derived SSTs from MODIS Aqua for the period January to December 2012. The images have a spatial resolution of approximately $9.2 \mathrm{~km}$. The global SMI data were subsampled from the region bounded by latitude from $33^{\circ}$ to $43^{\circ} \mathrm{S}$ and longitude from $49^{\circ}$ to $65^{\circ} \mathrm{W}$. The satellite data were extracted from the sea $2 \mathrm{~km}$ off the coast. To evaluate seasonal variation in oocyte diameter, we performed a Kruskal-Wallis test and a pairwise comparison test of ranks. 
Female

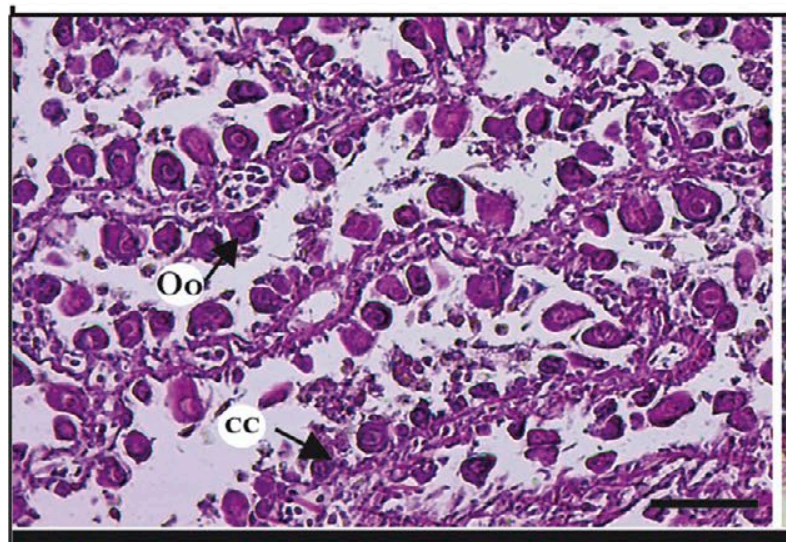

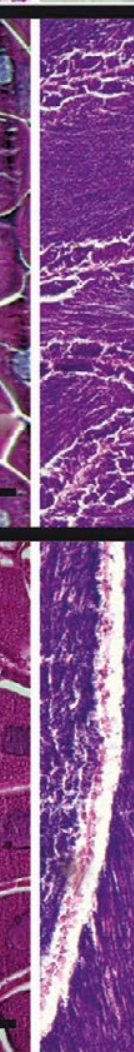

Male
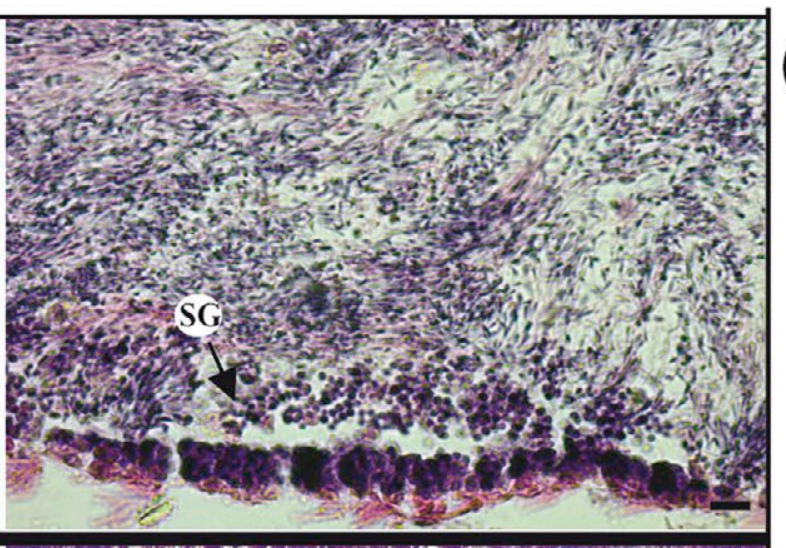

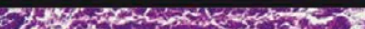

(2)
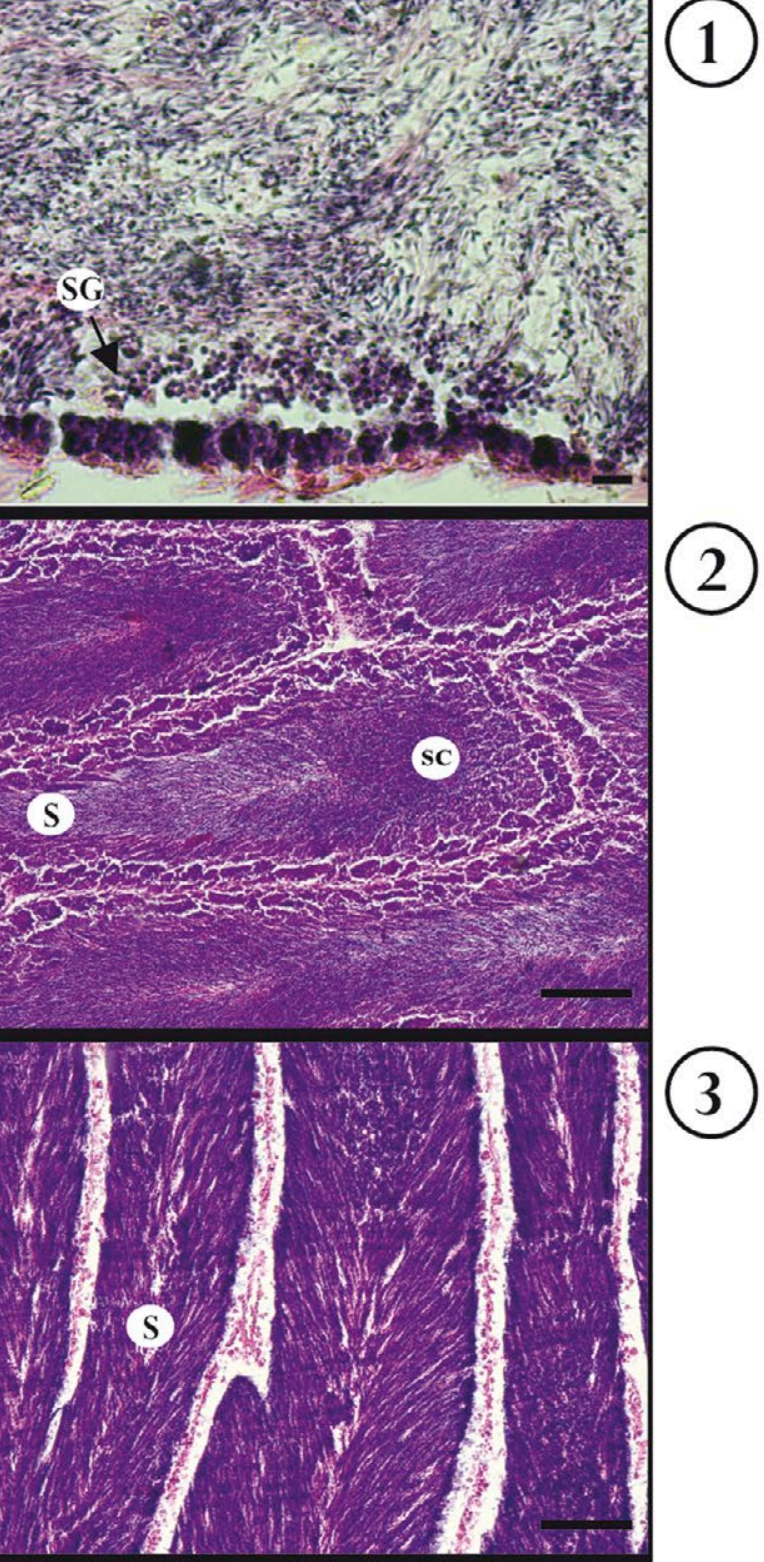

sc

\section{(s)}

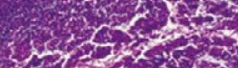

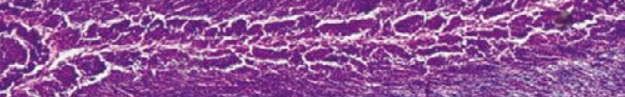

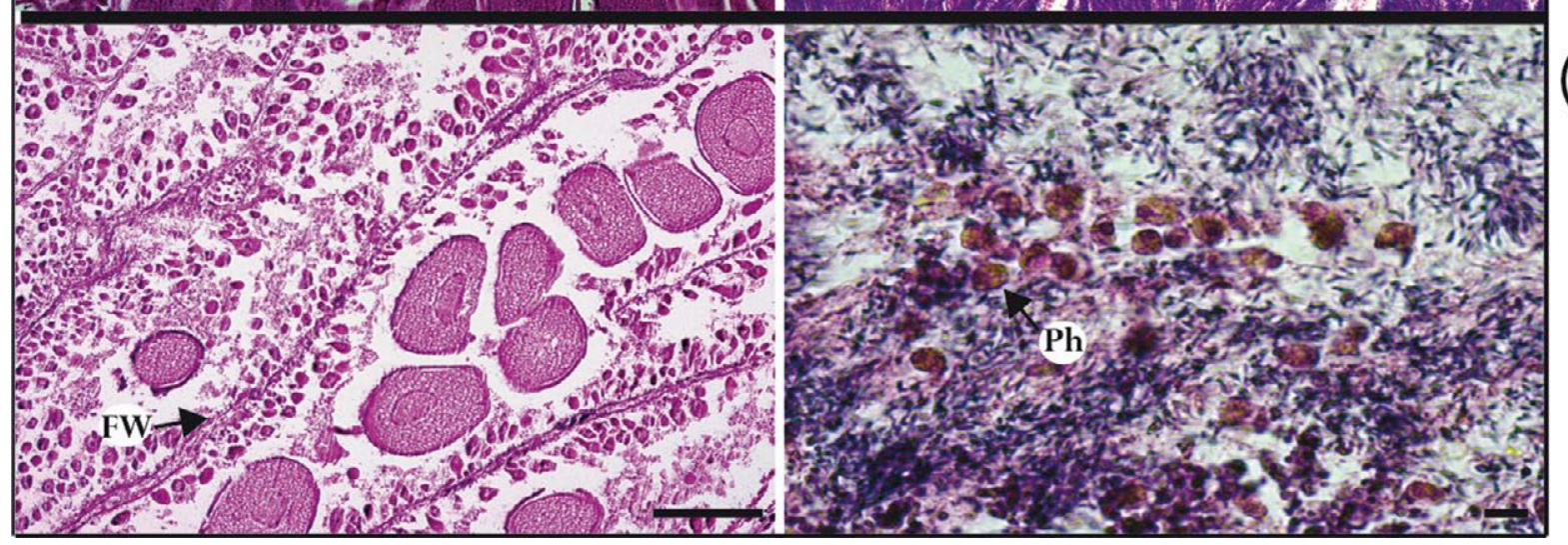

Fig. 1. - Gonadal stages for females (left) and males (right), 1, Developing; 2, Ripe; 3, Spawning; 4, Resorption. Abbreviations: oocytes (Oo), companion cell $(\mathrm{CC})$, nucleus $(\mathrm{N})$, follicular wall (FW), spermatocytes (SC), spermatozoa (S), phagocytes (Ph). Scale bar females: 100 um. Scale bar males 1-4: $10 \mu \mathrm{m} ; 2-3: 100 \mu \mathrm{m}$. 
Table 3. - Monthly variation in the percentage values of proteins, lipids, carbohydrates, ashes (dry weight) and humidity. The ashes proportion includes the inorganic matter in the analysed individuals. Oocyte mean value in $\mu \mathrm{m}$; oocyte modal diameters in $\mu \mathrm{m}$, first and second modal values. Prevalence: percentage of parasitized gonads in each month. *: no data due to lack of sampling.

\begin{tabular}{|c|c|c|c|c|c|c|c|c|c|}
\hline & $\begin{array}{c}\text { Protein } \\
\%\end{array}$ & $\underset{\%}{\text { Lipid }}$ & $\begin{array}{c}\text { Carbohydrate } \\
\% \\
\end{array}$ & $\begin{array}{c}\text { Ashes } \\
\%\end{array}$ & $\begin{array}{c}\text { Humidity } \\
\%\end{array}$ & $\begin{array}{l}\text { Oocyte } \\
\text { mean }\end{array}$ & $\begin{array}{l}\text { Oocyte } \\
1^{\text {st }} \text { mode }\end{array}$ & $\begin{array}{c}\text { Oocyte } \\
2^{\text {nd }} \text { mode }\end{array}$ & Prevalence \\
\hline January & $19.9 \pm 3.8$ & $3.3 \pm 0.3$ & $2.4 \pm 0.4$ & 14.42 & 78.03 & 14 & 12 & & 13 \\
\hline February & $22.8 \pm 4.1$ & $2.9 \pm 0.3$ & $0.4 \pm 0.3$ & 41.15 & 80.87 & 12 & 11 & & 10 \\
\hline March & $25.8 \pm 4.9$ & $2.7 \pm 0.08$ & $1.31 \pm 0.1$ & 21.60 & 84.12 & 58 & 16 & 129 & 3 \\
\hline April & $63.4 \pm 12.2$ & $3.3 \pm 0.2$ & $1.1 \pm 0.07$ & 20.68 & 84.27 & 213 & 129 & & 7 \\
\hline May & * & * & * & * & * & * & * & $*$ & $*$ \\
\hline June & $59.2 \pm 18.4$ & $2.4 \pm 0.2$ & $0.9 \pm 0.2$ & 30.48 & 82.95 & 125 & 129 & & 0 \\
\hline July & $10.3 \pm 4.5$ & $2.2 \pm 0.1$ & $0.4 \pm 0.02$ & 29.70 & 80.55 & 113 & 123 & & 3 \\
\hline August & $27.3 \pm 2.1$ & $2.1 \pm 0.09$ & $1.2 \pm 0.3$ & 27.46 & 82.89 & 122 & 129 & & 0 \\
\hline September & $33.3 \pm 3.6$ & $2.4 \pm 0.3$ & $1.4 \pm 0.6$ & 24.85 & 80.10 & 118 & 111 & & 7 \\
\hline October & $18.7 \pm 1.2$ & $2.6 \pm 0.05$ & $5.4 \pm 0.8$ & 18.45 & 81.23 & 124 & 145 & 23 & 7 \\
\hline November & $16.9 \pm 7.2$ & $2.8 \pm 0.2$ & $2.5 \pm 0.2$ & 25.91 & 82.44 & 121 & 116 & & 7 \\
\hline December & $30.3 \pm 0.3$ & $2.9 \pm 0.4$ & $2.7 \pm 0.9$ & 20.49 & 82.44 & 48 & 24 & 113 & 13 \\
\hline
\end{tabular}

\section{RESULTS}

Of the 358 Nacella magellanica sampled, 176 were females, 170 were males and 12 were indeterminate. The sex ratio in the $N$. magellanica population from Punta Ninfas was not significantly different from parity $(1: 1, n=346$, d.f. $=1, P>0.05)$ throughout the study period. The female mean total weight $(12.05 \pm 3.75$ g) and body weight $(6.23 \pm 2.0 \mathrm{~g})$ were significantly higher $(\mathrm{P}<0.05)$ than those of males $(10.22 \pm 3.34 \mathrm{~g}$ and $5.23 \pm 1.8 \mathrm{~g}$, respectively). The average female height $(1.98 \pm 0.31 \mathrm{~cm})$ and width $(3.82 \pm 0.37 \mathrm{~cm})$ were significantly higher $(\mathrm{P}<0.05)$, than those of males $(1.89 \pm 0.28$ $\mathrm{cm}$ and $3.68 \pm 0.34 \mathrm{~cm}$, respectively). The average length was similar in both sexes: $3.07 \pm 0.32 \mathrm{~cm}$ in females and $3.01 \pm 0.29 \mathrm{~cm}$ in males $(\mathrm{P}>0.05)$.

\section{Gonadal cycle}

We found a gonad coloration pattern across the reproductive cycle; in the case of females, green gonads recorded during maturation become darker in totally spawned specimens. In males, the gonad was yellow upon maturing and in ripe (fully mature) specimens, but brown in individuals after gamete release. Of 30 fixed specimens, only a mean of 10 were suitable for gonadal determination, because of rupture of several slides caused by sand content in the gut or because they were full of parasites Gymnophalloides (Table 1). Castration due to digenean parasites (Gymnophalloides), a phenomenon well described previously for this species (Cremonte et al. 2013, Bagnato et al. 2015), was detected in $16 \%$ of the analysed individuals (Table 3 ).

The monthly value of the oocyte modal diameter, from January to December 2012, ranged from $12 \mu \mathrm{m}$ in January and February to $145 \mu \mathrm{m}$ in October. We observed two modal diameters in several months due to the presence of growing and ready-to-spawn oocytes (Table 3). The low oocyte modal diameter observed in January, February and March (12-16 $\mu \mathrm{m})$ may correspond to a phase of recovering after spawning, with resorption and gamete developing, and the gonad shows a developing stage in March, with oocytes with a modal diameter of $129 \mu \mathrm{m}$. This stage continued until September, with an increase in the oocyte size until spawning; in October a second developing period

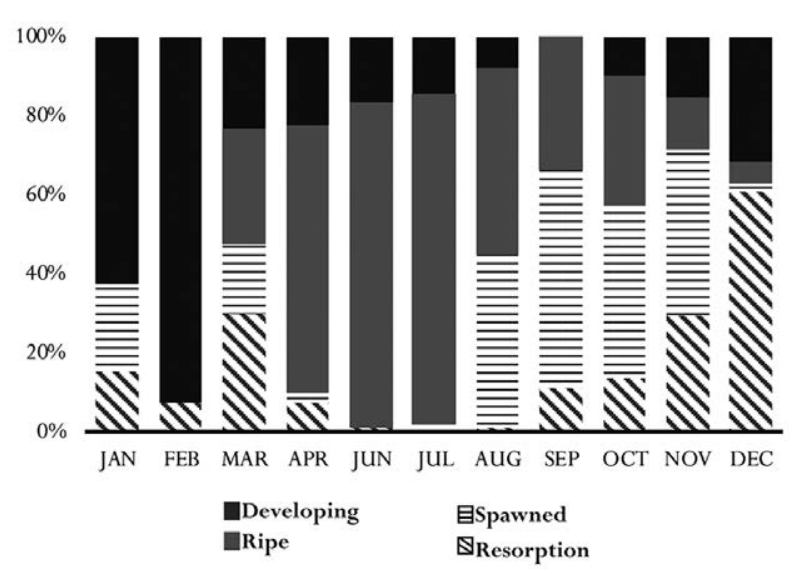

Fig. 2. - Female gonadal stages as determined from histological analysis. Key to bar textures: black, developing; grey, ripe; crosshatched, spawned; diagonally hatched, resorption.

started and continued with the increase and spawning (Table 3, Fig. 1). Oocytes with mode diameters bigger than $140 \mu \mathrm{m}$ seemed to be mature and ready to spawn when we recorded them free in the gonadal lumen.

We observed that female gamete liberation is low in January, March and April and increases in August, continuing until the end of the year (Fig. 2). The male gametogenic cycle was different to the female one (Fig. 3). The first individuals in the ripe stage appeared

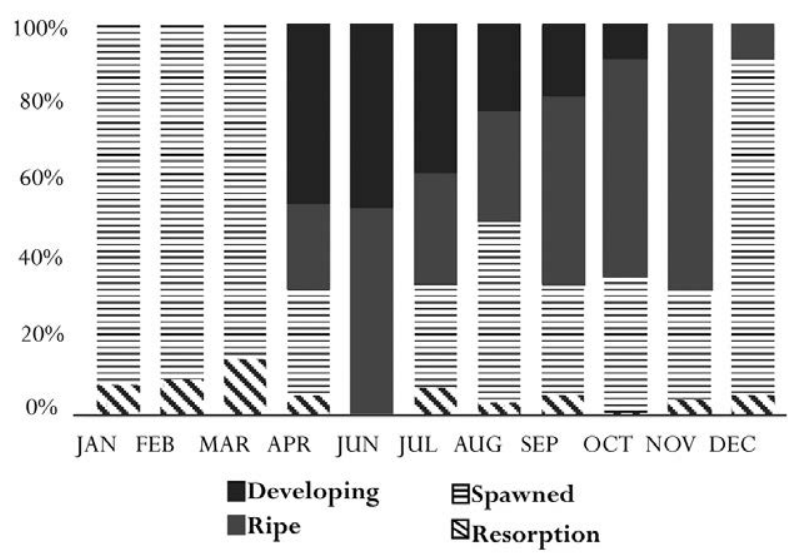

Fig. 3. - Male gonadal stages as determined from histological analysis. Key to bar textures: Black, developing; grey, ripe; crosshatched, spawned; diagonally hatched, resorption. 


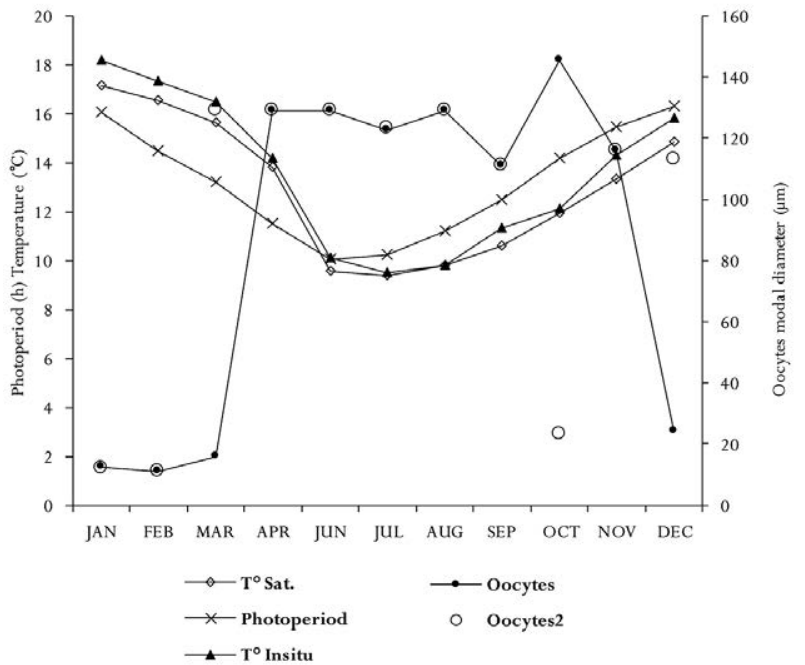

Fig. 4. - Variation in seawater surface temperature (satellite and in situ measurements), photoperiod and female oocyte modal diameter (oocytes 1 and 2 when more than one modal diameter was found) throughout the year 2012 .

from April to December, with a maximum in November. Gamete release in males occurred throughout most of the year, except in June. Thereafter, resorption was found throughout the year except in June and October.

Although histological sections of $N$. magellanica showed that individuals were in more than one gonadal stage (Figs 2 and 3 ) at the same time, we were able to determine a relationship between the oocyte sizes and the seasons. With a rank comparison we found three groups (selected by oocyte size) that were significantly different $(\mathrm{P}<0.05)$ : A, summer oocytes with a low size; $\mathrm{B}$, autumn oocytes with a medium size; and $\mathrm{C}$, spring and winter oocytes grouped together.

Sea temperature values recorded in situ were similar to those recorded by satellite (Fig. 4). Throughout the sampling period the measurements made by the MODIS Aqua satellite recorded an average water surface temperature of $12.8^{\circ} \mathrm{C}\left(\max .17 .13^{\circ} \mathrm{C}\right.$, min. $\left.8.72^{\circ} \mathrm{C}\right)$ and a mean photoperiod of $13.0 \mathrm{~h}(\max .16 .3$ $\mathrm{h}$, min. $10.06 \mathrm{~h}$ ). The increase in photoperiod started after 21 June and reached a maximum of $16.3 \mathrm{~h}$ of light in December, while the SST began to increase in August and reached its maximum value of $17^{\circ} \mathrm{C}$ in January (satellite information, Fig. 4). The spawning started in August and continued until December, with the concomitant increase in the water temperature (Fig. 4). During the autumn and winter (March to August), the oocytes became mature, with diameters greater than $140 \mu \mathrm{m}$ before gamete release in spring (September, October and November). Between the seasons, the average size of the oocytes was significantly higher in winter $(120.72 \mu \mathrm{m})$ and spring $(122.54 \mu \mathrm{m})(\mathrm{P}<0.05)$. The smallest mean value was recorded during the summer $(32.4 \mu \mathrm{m})$.

Finally, the female spawning period for $N$. magellanica was associated with a decrease in body weight (Fig. 5). During the month of July, when the gonads were mature and ready to spawn, the body weight underwent a slight increase, and decreased later during the spring spawning peak.

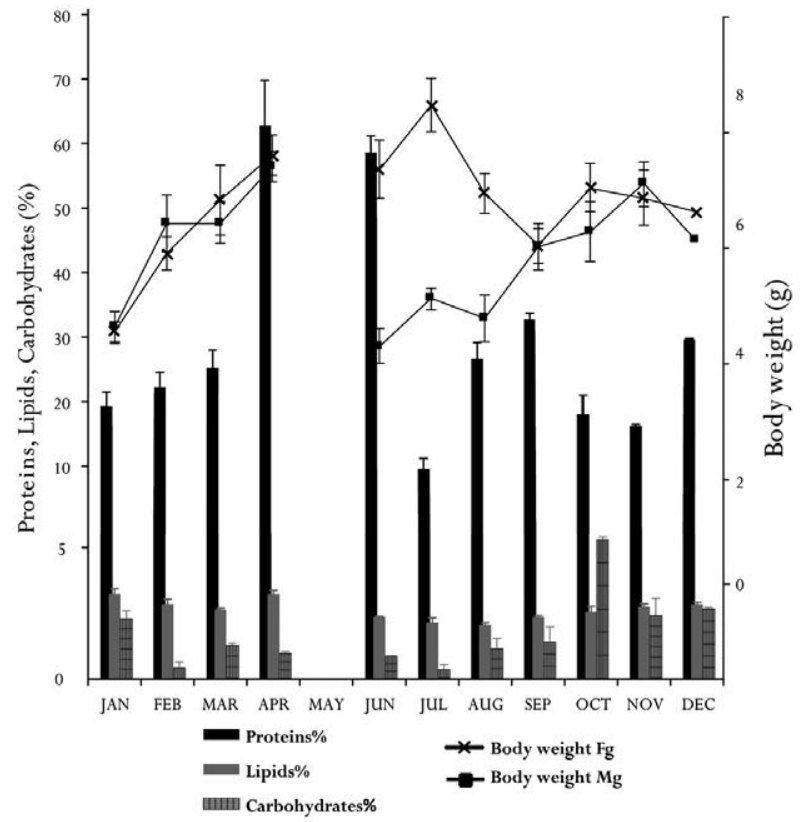

Fig. 5. - Nacella magellanica seasonal percent values for proteins (black bars), lipids (dark-grey bars) and carbohydrates (grid bars), and body weight for females (solid line) and males (hatched line) in 2012. Abbreviations: M, males; F, females.

\section{Nutritional composition}

Results of biochemical analysis are shown in Table 3 . The average nutritional values (dry weight) were $29.8 \pm 3.25 \%$ proteins, $2.71 \pm 0.12 \%$ lipids, and $1.8 \pm 0.26 \%$ carbohydrates. The average ash content was $25.0 \pm 2.2 \%$ and the average moisture $81.8 \pm 0.6 \%$. The abnormally high percentages of ashes are related to the abundant content of inorganic sediment particles within the organism's digestive system. Average seasonal concentrations showed no significant variations for proteins, but for lipids the winter average was significantly lower than that of the other seasons $(\mathrm{P}<0.05)$, while for carbohydrates the winter and spring averages were significantly lower and higher, respectively, than those of the other seasons $(\mathrm{P}<0.05)$.

We found a body weight variation in males and females across the sample period, though female body weight remained higher than male body weight during most of the year. Proteins were high in April and June, lipids remained low throughout the year with a slight decrease during the spawning period (Table 3), and carbohydrates increased during the spawning period with a maximum in October (Fig. 5).

\section{DISCUSSION}

The nutritional values of Nacella magellanica are within the ranges of those of widely consumed species of molluscs. The spawning period is related to changes in environmental conditions, such as the photoperiod and temperature of southern latitudes in the southwestern Atlantic.

The spawning period recorded in N. magellanica differed from that of previous studies on the southern species Nacella deaurata from the Beagle Channel 
$\left(54^{\circ} \mathrm{S}\right)$, in which the female gamete liberation period was only in spring (September, October, November) (Morriconi 1999), whereas we detected females spawning during a longer period, from late winter to summer. This prolonged period of gamete release of $N$. magellanica could be related to more favourable environmental conditions, principally the temperature and photoperiod (Clarke 1992, Bigatti et al. 2008, Cumplido et al. 2011). In this intertidal species, the interaction between increasing photoperiod and temperature is likely reflected in oocyte maturation and related to changes in body weight. Oocytes began to grow in April just after the peak in temperature, attaining their largest mean size in October, and the spawning period started together with the rise in water temperature. We found females in the spawning period with oocyte diameters greater than $140 \mu \mathrm{m}$, a similar size to that described for the limpet Patella Linnaeus (Branch 1975, Morriconi 1999). This oocyte size was related to the production of free planktotrophic larvae in other species (Picken 1980, Morriconi 1999), so we expected the same type of larvae for N. magellanica.

The digenea found in the gonadal tissue were described by Cremonte et al. (2013) in the same species. Although this parasite can represent a risk for humans, it can be controlled by avoiding consuming raw or improperly cooked molluscs (Lee and Chai 2001).

The nutritional values recorded in this work are similar to those of two other marine gastropods, Strombus gracilior, a common seafood in Mexico on the Pacific coast, which has an average protein content of $16.1 \%$, a lipid content of $1.4 \%$ and a carbohydrate content of $2 \%$ (Jiménez-Arce 1993), and Hexaplex trunculus, a popular seafood throughout the Mediterranean coast, which has an average protein content of $15.86 \%$, a lipid content of $1.14 \%$ and a carbohydrate content of $1.47 \%$ (Gharsallah et al. 2010). However, in the tropical abalone Haliotis varia (Najmudeen 2007), Babylonia spirata (Periyasamy et al. 2011) and the oyster Crassostrea gigas (Ren et al. 2003), the protein content $(76.4 \%, 53.86 \%$, and $71.5 \%$, respectively) and lipid content $(2.64 \%, 9.3 \%$ and $4.5 \%$, respectively) are higher than in N. magellanica.

Recent studies on the nutritional properties of $N$. $m a-$ gellanica from the same study area have demonstrated the presence of polyunsaturated fatty acids-including the nutritionally essential species arachidonic acid $(\omega 6)$, eicosapentaenoic acid $(\omega 3)$ and docosahexaenoic acid ( $\omega 3)$ _ at values of about $16 \%$ of total fatty acids (Bigatti et al. 2017). Therefore, because of its salubrious nutritional properties and the ease of collection and processing, N. magellanica should be considered an optimally desirable seafood for human consumption. However, cadmium concentrations up to $4 \mu \mathrm{g} / \mathrm{g}$ (ww) were also found in organs of $N$. magellanica and around $3 \mu \mathrm{g} / \mathrm{g}$ (ww) in the muscle (edible part) in the same study area (Bigatti et al. 2017). Due to the potential human risk, the presence of trace metals should be determined in each exploited population. A possible way to study pollutant depuration in short periods has been found by aquaculture, in which the species can be fed experimentally with biofilm plates (Nieto Vilela unpublished data).
The high concentration of protein found in April and June has no clear correlation with the abundance of available food to be expected in spring and summer (Giese 1967, Morais et al. 2003, Najmudeen 2007), so it could be attributed to reserves after the ingestion of biofilms prior to this month that are energetically favourable for the gamete-developing period. High protein proportions were also found in the Antarctic Nacella concinna (Congjie et al. 2005), which would indicate that the genus Nacella can store high protein concentrations naturally. The highest concentration of lipids in April is probably related to the food intake during the summer and the occurrence of gametogenesis at that time.

In general, marine invertebrates with external fecundity require reserves of carbohydrates to survive within the environment (Spikes 1949, Anderson and Personne 1970). Because carbohydrates are the primary energy source of molluscs (Barber and Blake 1981), the decline observed in the percentages of total body carbohydrates in N. magellanica in July could be attributable to a drop in glycogen levels as a result of the usual shortage of food in the winter (Morais et al. 2003, Ren et al. 2003). Furthermore, since carbohydrates are transformed into lipids during gamete formation (Ren et al. 2003), a decrease in the percentage of carbohydrates during gametogenesis might also be expected.

The annual nutritional values and the reproductive cycle reported here can enhance and expand current efforts to protect and conscientiously exploit this commonly consumed resource. According to our results, the optimum values for human consumption (i.e. the highest concentration of proteins, the highest body weight and the gonadal stage) are in April, corresponding to the austral autumn. The capture of the species in this season is recommended only if the minimum size of capture, $2 \mathrm{~cm}$, is respected, as stated in fishery regulation 199/18 (Secretaría de Pesca del Chubut) based on preliminary studies of Nieto Vilela (2014), allowing at least two spawning periods to ensure the sustainability of the resource.

\section{ACKNOWLEDGEMENTS}

The authors thanks Julio Rúa, Nestor Ortiz and Ricardo Vera for field logistics, and Estefania Bagnato, Nuria Vazquez and Carmen Gilardoni for determining the parasite species. Erica Giarratano, Mauricio Faleschini and Carmen Marinho helped in the laboratory analysis. Dr Donald F. Haggerty, a retired academic career investigator and native English speaker, edited the final version of the manuscript. RNV, MC, GB and MNG are members of CONICET. This manuscript was substantially improved by comments from two anonymous reviewers and the editors. This is publication 109 of the Laboratorio de Reproducción y Biología Integrativa de Invertebrados Marinos (LARBIM).

\section{REFERENCES}

Aji L.P. 2011. Spawning Induction in Bivalve. J. Pen. Sains 14: 2. Anderson W.A., Personne P. 1970. The localization of glycogen in the spermatozoa of various invertebrate and vertebrate species. 
J. Cell. Biol. 44: 29-51.

https://doi.org/10.1083/jcb.44.1.29

Averbuj A., Bigatti G., Penchaszadeh P.E. 2010. Gametogenic cycle and size at first maturity of the patagonic edible snail Buccinanops cochlidium from Argentina. Mar. Biol. 157: 2229-2240. https://doi.org/10.1007/s00227-010-1488-3

Bagnato E., Gilardoni C., Di Giorgio G., et al. 2015. A checklist of marine larval trematodes (Digenea) in molluscs from Argentina, Southwestern Atlantic coast. Check List 11: 1706. https://doi.org/10.15560/11.4.1706

Barber B.J., Blake N.J. 1981. Energy storage and utilization in relation to gametogenesis in Argopecten irradians concentricus (Say). J. Exp. Mar. Biol. Ecol. 52: 121-134. https://doi.org/10.1016/0022-0981(81)90031-9

Bigatti G., Ciocco N.F. 2008. Volutid snails as an alternative resource for artisanal fisheries in northern Patagonic gulfs. Availability and first suggestions for diving catches. J. Shellfish. Res. 27: 417-421.

https://doi.org/10.2983/0730-8000(2008)27[417:VSAAAR]2. $0 . \mathrm{CO} ; 2$

Bigatti G., Marzinelli E.M., Penchaszadeh P.E. 2008. Seasonal reproduction and sexual maturity of Odontocymbiola magellanica (Neogastropoda: Volutidae). Invertebr. Biol. 127: 314-326. https://doi.org/10.1111/j.1744-7410.2008.00139.x

Bigatti G., Cumplido M., Averbuj A. 2015. Gasterópodos de interés comercial en la Provincia del Chubut. LAPEMAR, Laboratorio de Peces y Mariscos de Interés Comercial (CENPAT). Report Lapemar 31.

Bigatti G., De Vivar M. D., Cumplido M., et al. 2017. Fatty acids and contaminants in edible marine gastropods from Patagonia. J. Mar. Biol. Ass. U.K. 98: 1355-1363. https://doi.org/10.1017/S0025315417000625

Branch G. 1975. Mechanisms reducing intraspecific competition in Patella spp.: migration, differentiation and territorial behavior. J. Anim. Ecol. 44: 575-600. https://doi.org/10.2307/3612

Castilla J.C. 1999. Coastal marine communities: trends and perspectives from human-exclusion experiments. Trends. Ecol. Evol. 14: $280-283$ https://doi.org/10.1016/S0169-5347(99)01602-X

Clarke A. 1992. Reproduction in the cold: Thorson revisited. Invertebr. Reprod. Dev. 22: 175-184. https://doi.org/10.1080/07924259.1992.9672270

Collin R. 2003. Worldwide patterns in mode of development in Calyptraeid gastropods. Mar. Ecol Prog. Ser. 247: 103-122. https://doi.org/10.3354/meps247103

Congjie D., Jianfeng H., Guizhong W., et al. 2005. Evaluation on nutritional composition of the soft part in Nacella concinna of great wall bay, Antarctica. Chin. J. Pol. Res. 17: 279-284.

Conti M.E., Stripeikis J., Botrè F., et al. 2012. Trace metals intake of Nacella $(P)$ magellanica from the Beagle Channel, Tierra del Fuego (Patagonia, Argentina). Int. J Environ. Res. Public. Health 6: 84-91.

https://doi.org/10.1504/IJENVH.2012.046857

Cremonte F., Pina S., Gilardoni C., et al. 2013. A new species of gymnophallid (Digenea) and an amended diagnosis of the genus Gymnophalloides Fujita, 1925. J. Parasitol. 99: 85-92. https://doi.org/10.1645/GE-2909.1

Cumplido M., Averbuj A., Bigatti G. 2010. Reproductive seasonality and oviposition induction in Trophon geversianus (Gastropoda: Muricidae) from Golfo Nuevo, Argentina. J. Shellfish Res. 29: 423-428. https://doi.org/10.2983/035.029.0219

Cumplido M., Pappalardo P., Fernandez M., et al. 2011. Embryonic development, feeding and intracapsular oxygen availability in Trophon geversianus (Gastropoda: Muricidae). J. Molluscan Stud. 77: 429-436. https://doi.org/10.1093/mollus/eyr025

D’Armas H., Yáñez D., Reyes D., et al. 2010. Composición de ácidos grasos de los caracoles marinos Phyllonotus pomum y Chicoreus brevifrons (Gastropoda: Muricidae). Int. J. Trop. Biol. 58: 645-654.

De Aranzamendi M.C., Gardenal C.N., Martin J.P., et al. 2009. Limpets of the genus Nacella (Patellogastropoda) from the southwestern Atlantic: Species identification based on molecular data. J. Molluscan Stud. 75: 241-251. https://doi.org/10.1093/mollus/eyp025

Elías I., Pereiro R. 2003. Estudios sobre la factibilidad de una pesquería artesanal con palangres en los golfos y costas de la provincia del Chubut, Argentina. INIDEP. Informe técnico 55:
$1-21$.

Fraga F. 1956. Determinación de glucógeno en moluscos con reactivo Antrona. Inv. Pesq. 3: 69-74.

Gabe M. 1968. Techniques histologiques. Masson, Paris, Vol. 427.

Gharsallah I., Vasconcelos P., Zamouri-Langar N., et al. 2010. Reproductive cycle and biochemical composition of Hexaplex trunculus (Gastropoda: Muricidae) from Bizerte Lagoon, northern Tunisia. Aquat. Biol. 10: 155-166. https://doi.org/10.3354/ab00275

Giese A.C. 1967. Some methods for study of the biochemical constitution of marine invertebrates. Oceanogr. Mar. Biol. Annu. Rev. 5: 159-186.

Gómez Otero J., Lanata J.L., Prieto A. 1998. Arqueología de la costa atlántica patagónica. Rev. Arque. Ame. 15: 107-185.

González-Wevar C.A., Hüne M., Cañete J.I., et al. 2012. Towards a model of postglacial biogeography in shallow marine species along the Patagonian province: lessons from the limpet Nacella magellanica (Gmelin, 1791). Evol. Biol. 12: 139. https://doi.org/10.1186/1471-2148-12-139

Horn A.C.M., Achaval A., Zancan D. 2005. The annual reproductive cycle of the snail Megalobulimus abbreviatus (Bequaert, 1948) (Gastropoda, Pulmonata). Braz. J. Biol. 65: 459-467. https://doi.org/10.1590/S1519-69842005000300011

Isay S.V., Busarova N.G. 1984. Study on fatty acid composition of marine organisms. Unsaturated fatty acids of Japan sea invertebrates. Comp. Physiol. Ecol. B 77: 803-810. https://doi.org/10.1016/0305-0491(84)90316-X

Jiménez-Arce G. 1993. Chemical and nutritional composition in the marine snail Strombus gracilior (Mesogastropoda: Strombidae) of various sizes and sexes in Playa Panamá, Costa Rica. Rev. Biol. Trop. 41: 345-349.

Lee S.H., Chai J.Y. 2001. A review of Gymnophalloides seoi (Digenea: Gymnophallidae) and human infections in the Republic of Korea. Korean J. Parasitol. 39: 85-118. https://doi.org/10.3347/kjp.2001.39.2.85

Leiva G.E., Castilla J.C. 2002. A review of the world marine Gastropod fishery: Evolution of catches, management and the Chilean experience. Rev. Fish. Biol. Fish. 11: 283-300. https://doi.org/10.1023/A:1021368216294

Lowry O.H., Farr A.L., Rosebrough N.J., et al. 1951. Protein measurement of emulsifying capacity by electrical resistance. J. Food. Sci. 193: 265-275.

Manzano N.B., Aranda D.A. 1998. Variación estacional de lípidos en varios tejidos del cambute Strombus gigas (Mesogastropoda: Strombidae), en Quintana Roo, México. Rev. Biol. Trop. 46: 655-660.

Morais S., Boaventura D., Narciso L., et al. 2003. Gonad development and fatty acid composition of Patella depressa Pennant (Gastropoda: Prosobranchia) populations with different patterns of spatial distribution, in exposed and sheltered sites. J. Exp. Mar. Biol. Ecol. 294: 61- 80. https://doi.org/10.1016/S0022-0981(03)00258-2

Mazurkiewicz M., Pokryszko B.M. 2005. Gametogenic cycle in Vertigo pusilla OF Muller, 1774 (Gastropoda: Pulmonata: Vertiginidae). Folia Malacol. 13: 43-47. https://doi.org/10.12657/folmal.013.006

Morriconi E. 1999. Reproductive biology of the limpet Nacella (P.) deaurata (Gmelin, 1791) in Bahía Lapataia (Beagle Channel). Sci. Mar. 63: 417-426. https://doi.org/10.3989/scimar.1999.63s1417

Najmudeen T.M. 2007. Variation in biochemical composition during gonad maturation of the tropical abalone Haliotis varia Linnaeus 1758 (Vetigastropoda: Haliotidae). Mar. Biol. Res. 3: 454-461. https://doi.org/10.1080/17451000701696252

Nieto Vilela R.A. 2014. Composición proximal y Toxina Paralizante de Moluscos en los gasterópodos con potencial pesquero Nacella magellanica y Tegula patagonica de Norpatagonia. Ph. D. thesis, Universidad de la Patagonia San Juan Bosco.

Orquera L.A. 1999. El consumo de moluscos por los canoeros del Extremo Austral. Rel. Soc. Arg. Antrop. 24: 307-328.

Pastorino G. 1995. Moluscos costeros recientes de Puerto Pirámide, Chubut, Argentina. Miscelánea 93, Acad. Nac. Cienc. Cordoba (Argentina), $30 \mathrm{pp}$

Periyasamy N., Srinivasan M., Devanathan K., et al. 2011. Nutritional value of gastropod Babylonia spirata (Linnaeus, 1758) from Thazhanguda, Southeast coast of India. Asian. Pac. J. Trop. Biomed. 1: 249-252. https://doi.org/10.1016/S2221-1691(11)60164-0

Penchaszadeh P., Sánchez Antelo C., Zabala S., et al. 2009. Re- 
production and imposex in the edible snail Adelomelon ancilla from northern Patagonia, Argentina. Mar. Biol. 156: 1929-1939. https://doi.org/10.1007/s00227-009-1225-y

Picken G. 1980. The distribution, growth, and reproduction of the Antarctic limpet Nacella (Patinigera) concinna (Strebel, 1908). J. Exp Mar. Biol. Ecol. 42: 71-85. https://doi.org/10.1016/0022-0981(80)90167-7

Pombo O.A., Escofet A. 1996. Effect of exploitation on the limpet Lottia gigantea: a field study in Baja California (Mexico) and California (USA). Oceanogr. Lit. Rev. 4: 387-388.

Powell A.W.B. 1973. The patellid limpets of the World (Patellidae). Indo-Pac. Moll. 3: 75-206.

Ramón M., Amor M.J. 2002. Reproductive cycle of Bolinus brandaris and penis and genital duct size variations in a population affected by imposex. J. Mar. Biol. Ass. UK 82: 435-442. https://doi.org/10.1017/S0025315402005696

Ren J.S., Marsden I.D., Ross A.H., et al. 2003. Seasonal variation in the reproductive activity and biochemical composition of the Pacific oyster (Crassostrea gigas) from the Marlborough Sounds, New Zealand. N Z J Mar. Freshw. Res. 37: 171-182. https://doi.org/10.1080/00288330.2003.9517155
Spikes J.D. 1949. Metabolism of sea urchin sperm. Am. Nat. 83: 285-301.

https://doi.org/10.1086/281606

Underwood A.J. 1979. The ecology of intertidal gastropods. Adv. Mar. Biol. 16: 111-210. https://doi.org/10.1016/S0065-2881(08)60293-X

Vasconcelos P., Carvalho S., Castro M., et al. 2008. The artisanal fishery for muricid gastropods (banded murex and purple dye murex) in the Ria Formosa lagoon (Algarve coast, southern Portugal). Sci. Mar. 72: 287-298.

Velasco L.A., Barros J., Acosta E. 2007. Spawning induction and early development of the Caribbean scallops Argopecten nucleus and Nodipecten nodosus. Aquaculture 266: 153-165. https://doi.org/10.1016/j.aquaculture.2007.02.015

Zöllner N., Kirsch K. 1962. Über die quantitative bestimmung von lipoiden (mikromethode) mittels der vielen natürlichen lipoiden (allen bekanneten plasmalipoiden) gemeinsamen sulfophosphovanilin-reaktion. Z. Gesamte. Exp. Med. 135: 545-561. https://doi.org/10.1007/BF02045455 